\title{
Some observations on a nickel stress telephone
}

\author{
F. J. Jervis-Smith M.A. F.R.S.
}

To cite this article: F. J. Jervis-Smith M.A. F.R.S. (1897) Some observations on a nickel stress telephone, Philosophical Magazine Series 5, 44:267, 211-211, DOI: 10.1080/14786449708621055

To link to this article: http://dx.doi.org/10.1080/14786449708621055

曲 Published online: 08 May 2009.

Submit your article to this journal 중

Џ Article views: 2

Q View related articles $\sqsubset$ 
impossible can be more or less clearly imagined by the mathematician.

It must not be forgotten that beside the resolution into plane waves dealt with above, there are an infinite number of resolutions into waves of other forms which are equally possible, and several of which present themselves in optical inquiries.

$$
\begin{aligned}
& \text { I am, Gentlemen, } \\
& \begin{array}{l}
\text { 8, Upper Hornsey Rise, N:, } \\
\text { July 14, 1897. }
\end{array}
\end{aligned}
$$

XXXI. Intelligence and Miscellaneous Articles.

SOME OBSERVATIONS ON A NICKEL STRESS TELEPHONE. BY

F. J. JERVIS-SMITH, M.A., F.R.S., MILLARD LECTURER, TRINITY COLLEGE, OXFORD.

$A^{T}$ page 26 of the present volume of the Philosophical MagaA zine a Nickel Stress Telephone is described by Messrs. Garrett and Lueas. When $I$ was working in 1891 on the magnetization of wires of iron, steel, and nickel, which had received a permanent set, I found that excellent telephonic effects could be produced by means of wires under stress (p. 395, Phil. Mag. 1891, vol. xxxii.). The authors of the paper mention the difficulty of comparing the speaking-powers of different instruments. I expect that a form of electrodynamometer, which was shown in the Electrical Exhibition in Paris of 1881, would be found of use in comparing the relative outputs of different kinds of telephonic apparatus. The instrument was constructed thus:-a small light coil, carried on a balanced arm hanging by a bifilar suspension, moved over a curved solenoid which passed through it. 'l'he alternating current generated by a telephone when transmitting a musical note gave a large deflexion of a light straw pointer attached to the suspended arm.

Oxford, July 2, 1897.

\section{ON THE INTERFERENCE, AND THE ELECTROSTATIC DEFLEXION OF KATHODE RAYS. BY PROFESSOR JAUMANN.}

Two parallel kathode plates at a distance of $2 \mathrm{~cm}$. from each other are connected by a wire loop $250 \mathrm{~cm}$. in length, and the megative current of an induction machine is passed by means of a sliding contact. By displacing this along the loop, with a suitable adjustment the bright sharp plane is displaced in which the two blue kathode lights interfere without becoming essentially broader. This, being an action of a slight difference in the conducting circuits to the kathodes, cannot be explained otherwise than as an interference of the kathode lights. The simple interference 